\title{
Entity With Role in Clinical Study
}

National Cancer Institute

\section{Source}

National Cancer Institute. Entity With Role in Clinical Study. NCI Thesaurus. Code C156779.

Any person or entity that has a role or participates in a clinical research study, including both study personnel and study subjects. 